\title{
Controlling Goods or Promoting the Public Good: Choices for Special Collections in the Marketplace
}

FOR THE PAST FEW decades, many special collections repositories in the United States have charged licensing or use fees to those patrons who use or publish special collections materials for commercial purposes. In fact, about fifteen years ago the Rare Books and Manuscripts Section of the Association of College and Research Libraries charged an ad hoc committee, the Licensing and Reproductions of Special Collections Committee, to "create a reasoned and articulate defense of libraries' right to charge licensing fees for commercial uses of their materials." noted that, historically, libraries allowed scholars to publish freely from the content they found in special collections. However, due to budget pressures facing libraries as well as marketplace shifts in the publishing industry, the Committee found it justifiable to charge fees to support or offset operational costs. They provided a rationale for charging publishing or commercial use fees and offered guidance on constructing a fee policy and structure.

At my institution, the University of Nevada, Las Vegas Libraries, we have a brisk business in the sale of photographs. Imagery of Las Vegas history has wide appeal, whether of the Rat Pack, the Wild West, showgirls, Glitter Gulch, or the Strip's distinctive architecture. Our content is used not only for scholarly works but also for television, films, wall décor, memorabilia, and much more. For several years, we required that anyone who wished to publish or display our images ask us for permission first. We assessed use fees, in addition to scanning fees, to those who used our materials for commercial purposes. For noncommercial users, we only assessed scanning fees to offset the labor costs associated with creating a reproduction. With both scanning and use fees, we generated enough revenue to cover at least half the salary of a library technician who managed reproductions.

We also have a robust digitization program and have received several grants to make our holdings available online. But, the more we digitize our holdings, the more people discover our content and want to use it. Our businesslike stance on

1. This paper is an expansion of a presentation delivered at a plenary about the "marketplace" at the RBMS Preconference in Las Vegas, Nevada on June 26, 2014.

2. Lisa Browar, Cathy Henderson, Michael North, and Tara Wenger, "Licensing the Use of Special Collections Materials,” RBM: A Journal of Rare Books, Manuscripts, and Cultural Heritage 3, no. 2 (2002): 124. 
selling reproductions often was coming into conflict with our altruistic motives for digitizing our content and making it widely accessible. Our digital collections site served simultaneously as a catalog to encourage discovery and support revenue generation, and we found it difficult to strike a balance in our services and interfaces for supporting free personal or educational use of our material while also restricting it for commercial purposes.

These conflicts led me to ask, "Why are we insisting that users ask us for permission to publish, and why are we charging additional fees for publishing and commercial use?" I heard a variety of answers. First, we own the material so we should have certain privileges for managing use of our physical property. Second, many other special collections require that users request permission to publish, and they also assess publication or use fees. We simply follow the practices of our peers. More compelling perhaps was the argument that we should share in any profit made from our holdings, especially because we invest so many resources to collect, organize, describe, and digitize this content. Also, our mission focuses on the academic enterprise, so we might be justified in charging those who are not using our materials for teaching, learning, or scholarship. Furthermore, we want to know how our content is being used, foremost for reporting purposes. When someone asks us for permission to publish, this transaction also provides us with an opportunity to ask users to cite our materials properly. Finally, we protect ourselves when our users sign an agreement stating that they will secure permissions from other rights holders and not hold us liable for how they use our collections.

As our images proliferated on the Internet with no attribution, permission, or payment, we began to notice that our permission requirements and use fees penalized the good citizens, that is, those who made the effort to contact us before using material they found online. To prevent unauthorized use, we investigated how we might erect barriers to ensure permission and payment, for example, with clickthrough agreements or user accounts.

In 2011 Jean Dryden asked 150 Canadian repositories why they controlled downstream usage of their digitized content. ${ }^{3}$ Reasons included a loss of revenue, threats to the authenticity of documents from improper captioning or manipulation, potentially compromising the repository, or fear of legal liability from researchers misusing material. Likewise, she noticed the "tension between an archival repository's mandate to provide access to its holdings and a desire to control further uses of them." She noted that repositories often conflated the rights unique to copyright

3. Jean Dryden, "Copyfraud or Legitimate Concerns Controlling Further Uses of Online Archival Holdings," American Archivist 74 (Fall/Winter 2011): 522-43.

4. Dryden, "Copyfraud or Legitimate Concerns," 539. 
holders with attempts to constrain use. She urged immediate action to change and correct these practices.

Inspired by this article to question my institution's practice and gain a better understanding of my peers' practices for handling permissions and user fees, I looked at the forms and procedures of 125 special collections in research libraries in the United States. I found that approximately 70 percent of special collections require users to seek permission to publish any content from their holdings. This includes seeking permission for public domain content, content that is copyrighted by others, and content with copyrights held by the institution. By contrast, 15 percent of these special collections only require permission to publish when the institution owns the copyright. Fifty-five percent of institutions charge use fees or permission fees, in addition to scanning fees, for publishing any content from their holdings. Most institutions had different price points for different kinds of use. Smaller or more scholarly publications were charged less than uses with larger audiences or larger profit potential. Twenty-five percent, however, did not charge any use fees beyond the scanning fees.

My research encouraged me to change our policies and practices at the UNLV Libraries. We no longer require users to seek permission to publish when we do not hold copyright, and we stopped assessing use or publication fees. We do charge scanning and service fees, however, that offset the costs of labor involved in fulfilling a reproduction order. We are also in the midst of overhauling our rights statements throughout our digital collections, finding aids, and catalog records. I urge our profession to do likewise. As digitization and online delivery are the new norm for special collections, I encourage institutions to question, review, and change their permission processes and use fee structures, especially for public domain materials and when they do not own the copyright. Our colleagues at institutions such as the Library of Congress; Cornell University; the Beinecke Library at Yale; University of Virginia; University of North Carolina, Chapel Hill; and others have already paved the way for change.

I put forward four reasons to change our practices. First, our practices are not always legal and may put our institutions at risk. Second, it is the right thing to do. Third, the costs of maintaining the infrastructure necessary to manage permissions and charge use fees are probably not worth the benefits. And finally, there are other ways to generate revenue that do not undermine our mission or core values.

\section{Copyright}

Many common practices for requiring users to seek permission to publish and for assessing publishing fees are not consistent with copyright law and may put your in- 
stitution at risk. If your institution owns the copyright to materials in a collection, then you certainly have the right to grant permission to publish and assess publication fees. But, in many manuscript or photograph collections, you may not know who holds the copyright in every item, even if you have a gift agreement transferring rights to your institution.

Copyright is the exclusive, legal right to publish, distribute, transfer ownership, reproduce, perform, display, and adapt a work, or the exclusive legal right to authorize these activities. ${ }^{5}$ It is designed to provide an author or artist with control over the dissemination and use of his or her works for a reasonable period of time as a financial incentive to create and develop arts, sciences, and culture. After that time, material passes into public domain to ensure the "Progress of Science and useful Arts."”

Based on the wording I found in many permission policies and forms, many special collections in U.S. research libraries erroneously believe that physical ownership gives them rights to determine how material is used after it is reproduced. They think that physical ownership gives them a "quasi-copyright-like control" so that they may control reuse based on their property rights. ${ }^{7}$ But the Copyright Act of 1976 clearly distinguished property rights from copyrights. ${ }^{8}$ Physical ownership means that you own the medium on which the intellectual content is stored. Physical ownership allows you to govern access to the material object. When we own a physical item, we can allow or deny access, or make access conditional on researchers agreeing to certain behaviors. ${ }^{9}$ We can assess fees

5. 17 U.S.C $\$ 106$.

6. United States Constitution, Article I, Section 8.

7. Peter Hirtle, "Archives or Assets?” American Archivist 66 (Fall/Winter 2003): 240.

8. 17 U.S.C $\$ 202$ : "Ownership of a copyright, or of any of the exclusive rights under a copyright, is distinct from ownership of any material object in which the work is embodied.” Granted, there are conflicting interpretations about how common-law copyrights might apply prior to the effective date of the 1976 Copyright Act for unpublished materials and about how they may or may not be tied to ownership. See, for example, the discussion about Pushman v. New York Graphic Society in Susan M. Bielstein, Permissions, A Survival Guide: Blunt Talk about Art as Intellectual Property (Chicago: University of Chicago Press, 2006), 29-31; and in Peter Hirtle, Emily Hudson, and Andrew T. Kenyon, Copyright \& Cultural Institutions: Guidelines for Digitization for U.S. Libraries, Archives, \& Museums (Ithaca: Cornell University Library, 2009), 64. In 1942 in New York, the Pushman decision suggested that transferring the only copy of an unpublished work also transferred copyright, but it was discredited by the New York legislature in 1966. The 1976 Copyright Act clarified any ambiguity. For a discussion of common-law copyrights governed by states for unpublished materials prior to the 1976 act, see Scott J. Burnham, "Copyright in LibraryHeld Materials: A Decision Tree for Librarians,” Library Law Journal 96, no. 3 (2004): 425-48. Another interesting explanation of common-law copyright and the common-law right of first publication prior to the 1976 act may be found in Kenneth Crews, "Unpublished Manuscripts and the Rights of Fair Use: Copyright Law and the Strategic Management of Information Resources," Rare Books and Manuscript Librarianship 5 (1990): 61-70.

9. For example, it is standard practice for researchers to sign an agreement about following the rules of our reading room before allowing them access to material. Bielstein explains that museums, according to the "law of forbearance," are within their rights, and courts are unlikely to intervene, in enforcing behavioral policies. "When you purchase a ticket to its galleries or ask to be admitted to the archive, you are entering into a compact that obliges you to abide by certain rules, including those that govern viewing and restrictions on photography." Bielstein, Permissions, A Survival Guide, 52. 
for the privilege of accessing the material, or assess fees for the act of creating the reproduction. But copyright is an exclusive right to authorize the reproduction of a work, to publish, and to create copies for sale. Only the copyright owner, or designee, can grant permission to publish a reproduction and charge for this permission.

If we do not own the copyright, we do not have these rights. If we create contracts with users that infringe on the copyright owner's exclusive rights to control publication, then we are putting ourselves at risk. If we make users ask us for permission to publish as a condition of access, federal copyright law, which gives the copyright holder the exclusive right to control permissions to publish, will most likely pre-empt our demands. If we attach fees with our permissions to publish, then we also infringe on copyright owners' rights to profit from their work. As Susan Bielstein bluntly states in her book about permissions: "The repro fee represents a not-so-subtle claim to the right to authorize the reproduction of a work, which the last time I checked (about three minutes ago), is the functional basis of copyright and not an automatic privilege of the owner of the material object." 10

There are certainly exceptions to copyright law that allow us to furnish copies of copyrighted material for private study, scholarship, and research. " "Fair use" is also increasingly seen as a way we can digitize and provide online access to our collections without our having to engage in burdensome permission processes. ${ }^{12}$ But granting permission and charging for publication puts Section 108 and fair use exemptions in jeopardy. In a recent study on the use of digital cameras in special collections reading rooms, the authors concluded, "Charging fees for reproductions of copyrighted material may place the institution at greater risk for copyright infringement. If fees are determined to provide 'direct or indirect advantage' to the repository, its Section 108 exemptions are lost and maintaining a 'fair use' defense becomes much harder." ${ }^{13}$ So in summary, I ask the 70 percent of special collections requiring permission to publish and the 55 percent charg-

10. Bielstein, Permissions, A Survival Guide, 56.

11. 17 U.S.C. $\S 108$.

12. Code of Best Practices in Fair Use for Academic and Research Libraries (Association of Research Libraries; Center for Social Media, School of Communication, American University; Program on Information Justice and Intellectual Property, Washington College of Law, American University, 2012), 20. "It is fair use to create digital versions of a library's special collections and archives and to make these versions electronically accessible in appropriate contexts." "The fair use case will be even stronger where items to be digitized consist largely of works, such as personal photographs, correspondence, or ephemera, whose owners are not exploiting the material commercially and likely could not be located to seek permission for new uses."

13. Lisa Miller, Steven K. Galbraith, and the RLG Partnership Working Group on Streamlining Photography and Scanning, for OCLC Research, Capture and Release: Digital Cameras in the Reading Room (Dublin, Ohio: OCLC Research, 2010), 10. 
ing publishing fees: are the fees and the control over publishing worth the risk to your institution ${ }^{14}$

\section{Ethics in the Public Domain}

After the term of copyright expires, material enters the public domain. Justice Louis Brandeis proclaimed that the material is "free as the air to common use." 15 Case law and legal scholars disagree about whether we can impose restrictions through contracts on the use of public domain works though ${ }^{16}$ Courts generally have agreed that owners may employ contracts to restrict use of the public domain material they publish. If the owner requires a user, as a condition of access, to accept an agreement that prohibits commercial reuse of their public domain material, then the user would be in violation of contract law if he or she republished the content without permission. The owner would not enforce copyright law, but rather contract law.

Even if we can do so legally, restricting access or charging for use of public domain works is not the right or ethical thing for special collections to do. When material is in the public domain, the content belongs to everyone. Anyone should be able to use

14. Peter Hirtle's blog post, "What the University of Arkansas controversy can teach us about archival permission practices," reinforces the risk to institutions. He wrote this post about a month after I delivered this plenary; otherwise, I would have quoted it more. He concluded, "A close examination of the 'permission to publish' policies of one typical institution demonstrates that they make little or no legal or policy sense. They can confuse researchers (and library staff) about the nature of the repository's rights in the material. They can place the repository in the unenviable and unsustainable position of having to assess the legality of the researcher's proposed use. Requirements for compensation (either directly or in the form of complimentary copies of publications) may negate the repository's normal defenses against a charge of copyright infringement for its copying." Peter Hirtle, "What the University of Arkansas controversy can teach us about archival permission practices," Library Law Blog (July 24, 2014), available online at http:/ / blog.librarylaw.com/librarylaw/2014/07/arkansas-and-archival-permission-practices.html [accessed 1 December 2014]. Rick Anderson, in his later blog post in Library Journal about the University of Arkansas situation, moves beyond a legal analysis to suggest that controlling use of content is antithetical to our values: "It's about whether we're abiding by the principles we claim as being core to our profession - in particular, those principles related to intellectual freedom, the public good, and service. It's one thing to require that rare or fragile documents be handled carefully and under supervision and to educate patrons about copyright law; it's quite another thing to require that patrons ask our permission before reusing the intellectual content of documents in the public domain and even (as many libraries do) to inform us ahead of time how they plan to use it." Rick Anderson, "Asserting Rights We Don't Have: Libraries and 'Permission to Publish,"” Library Journal (Aug. 21, 2014), available online at http:/ / lj.libraryjournal.com/2014/08/opinion/peer-to-peer-review/asserting-rightswe-dont-have-libraries-and-permission-to-publish-peer-to-peer-review/ [accessed 1 December 2014].

15. International News Service v Associated Press, 248 U.S.215, 250 (1918) (Brandeis, J. dissenting).

16. See Peter Hirtle's discussion about the Smithsonian's use of a click-through agreement to control subsequent use of public domain material on their site: Peter Hirtle, "Smithsonian's Control of PD Images,” Library Law Blog (May 20, 2007), available online at http:/ / blog.librarylaw.com/librarylaw/2007/05 / smithsonians_co.html [accessed 26 November 2014]. A lawsuit brought against the Berkeley Historical Society poses similar question. See Mary Minow, "Berkeley Historical Society lawsuit: Can a library, museum or archive charge money for photos that are in the public domain?” Library Law Blog (Aug. 25, 2005), available online at http://blog.librarylaw.com/librarylaw/digitization_projects_/ [accessed 26 November 2014]. Beginning with ProCD vs. Zeidenberg in 1996, courts have held that owners of public domain material may restrict subsequent use of that material with contracts. Several legal scholars have written about this case and its potential to undermine the public domain. A basic overview may be found in Stephen Fishman, The Public Domain: How to Find \& Use Copyright-Free Writings, Music, Art \& More (NOLO, 2012), 26-28. 
or sell copies of this material without penalty or permission. As Peter Hirtle noted in his 2003 presidential address to the Society of American Archivists, "Efforts to try to monopolize our holdings and generate revenue by exploiting our physical ownership of public domain works should not succeed. Such efforts make a mockery of the copyright balance between the interests of the copyright creator and the public. They ignore the public's ownership interest in our holdings." ${ }^{17}$ If you are part of an institution committed to the advancement of knowledge through teaching and research, then making public domain material freely available is consistent with this mission to disseminate knowledge, encourage appreciation of our cultural heritage, and inspire creativity. Moreover, it is consistent with our professional values, whether you might be a librarian or archivist. Rather than treating our content as goods we control in the marketplace, let us see our responsibility as promoting the public good. ${ }^{18}$

In recent literature, you may have noticed the dire rhetoric about the public domain, that there is a war against it, that is shrinking and in danger of being lost, and that we need a call to arms to preserve it. One of the villains is "copyfraud"; that is to say, when you claim copyright ownership over public domain content or when you overreach the law to restrict access to content to which you do not have rights. Jason Mazzone originally coined the term "copyfraud" and called out archives specifically as claiming "blanket copyright in everything in their collections, including historical works as to which copyright, which likely never belonged to the archive in the first place, has long expired." ${ }^{19}$ In her study of Canadian archival reposito-

\footnotetext{
17. Hirtle, "Archives or Assets?" 245.

18. I am joining the chorus in this appeal. The Advocacy Agenda for the American Library Association, for example, includes support for protecting and extending the public domain. For a perspective from the Getty, see Kenneth Hamma, "Public Domain Art in an Age of Easier Mechanical Reproducibility," D-Lib Magazine 11, no. 11 (Nov. 2005). He argues that "making visual reproductions of public domain art works available for use and reuse without charge would likely benefit the collecting institutions and would contribute to the public good." The Google Books project, which digitized and provided online access to over 2 million public domain books, quotes several partner libraries describing their participation as in keeping with their missions to support public knowledge, public discourse, and the public good. See Google Books, "Library Partners," available online at https: / / www.google.com/googlebooks/library/partners.html [accessed 26 November 2014].

19. Jason Mazzone, "Copyfraud," New York University Law Review 81 (2006): 1029. He limited the definition of copyfraud to "claiming falsely a copyright in a public domain work," but others have expanded it. Mazzone explains that "publishers and the owners of physical copies of works plaster copyright notices on everything. These publishers and owners also restrict copying and extract payment from individuals who do not know better or find it preferable not to risk a lawsuit. These circumstances have produced fraud on an untold scale, with millions of works in the public domain deemed copyrighted and countless dollars paid out every year in licensing fees to make copies that could be made for free." He cites the consequences as well: "In addition to enriching publishers who assert false copyright claims at the expense of legitimate users, copyfraud stifles valid forms of reproduction and creativity and undermines free speech." Mazzone, "Copyfraud," 1030. He calls out the American Antiquarian Society, in particular, as a problematic offender. Even though most of their materials are in the public domain, their website stated that " "[a]11 uses... of images from the collection[ ]... must be licensed by the Society in consequence of its proprietary rights.' The Society licenses images (including engravings, prints, photographs, art works, and pages from books and manuscripts) at a rate of $\$ 100$ each for reproduction in a commercial work.' According to the Society's "License Agreement," it "owns various proprietary materials protected by common law, copyright laws and/or other applicable laws restricting use of such materials. '...Further, "the Society may require... the [Licensee's] Project...to bear a credit line and/or a permanently affixed copyright notice in the Society's name (i.e., '(C) American Antiquarian Society').” Mazzone, "Copyfraud," 1053.
} 
ries, Jean Dryden concluded that some institutions were guilty of copyfraud when they required "end-users to obtain the repository's permission to publish even if the repository has no copyright interest in the work involved." ${ }^{20}$ In this battle to preserve the public domain and advance human knowledge, what side should your institution be on?

Use fees also have a chilling effect on scholarly publishing. Authors and publishers will publish less when the costs are high. Our use fees function to create disincentives or barriers, and limit the amount of our material that is exchanged. Consider this statement from the College Art Association: "These fees ... are contributing to overall rising costs of scholarship in the field; but worse, they may be contributing to an actual decline in the quality of scholarship. That is to say, the presence of such charges undoubtedly inhibits the use of visual support for argumentation. In some documented cases the level of costs involved has resulted in cancellation of an important publication project." ${ }^{21}$ Is this the restrictive influence we want on the publishing market?

Perhaps worse yet, our barriers may drive researchers off. We do not always have the monopoly on content; and, if our demands are too high, our customers will seek alternative suppliers for content, or they will just decide to do something different entirely. The end results are fewer patrons and fewer people who will ultimately become aware of, see, or appreciate our content. For the 70 percent requiring permissions or the 55 percent charging fees, is this your intention?

Another irony is that, although we want more people to appreciate us and our holdings, we charge the highest use fees for those projects that will allow the most people to see and appreciate our content. Is it really so bad if we help our researchers make money from using the content we collect? Perhaps we should think instead of the potential reach to new audiences or the opportunity to demonstrate our institution's economic impact. Are we charging more for wider distribution as a way of discouraging consumption, to prevent the devaluation or cheapening of our content by ensuring its rarity or to ensure that it is used in respectful contexts? Are we engaging in self-preservation? I believe we improve our society by increasing the distribution of the materials we collect, by making them more visible and available for inclusion in public discourse. Kathleen Butler, in her article "Keeping the World Safe from Naked-Chicks-in-Art Refrigerator Magnets," encourages the democratization of cultural heritage, for museums to allow the transformation of

20. Dryden, "Copyfraud or Legitimate Concerns," 541.

21. College Art Association, "Statement Regarding National Policy on Granting of Reproduction Rights in Art-Historical Publishing," available online at www.collegeart.org/guidelines/reprorights [accessed 26 November 2014]. 
art into usable images that people can use in their everyday lives. ${ }^{22}$ This applies to special collections too. Widespread visibility of our content would make for a better, not a worse, world.

\section{Costs}

Based on my experience, the costs of maintaining a permissions infrastructure are usually not worth the benefits. My guess is that, for the majority of institutions in my study, the total cost in time and staff, as well as the amount of headache and ill will generated, to control reproductions, manage permissions, and charge permission fees exceed the gain in revenue and control. Before we changed our policies and fees at UNLV, I was constantly asked to intervene in patrons' protests over fees. Many commercial patrons wished to plead their case for price reductions or negotiate a better deal directly with me. Quite regularly, we were cast as the bad guys in major reproduction orders, and I wanted to find ways to be the good guys.

Since we let go of granting permissions and charging permission fees, I rarely receive phone calls or e-mails from angry or desperate patrons. I receive far more thank-yous for efficient and helpful service, and public services staff members handle almost all of the reproductions orders without my intervention. All of this is anecdotal, of course, but it makes sense. If your institution stops requiring or granting permissions, and your fees simply recover costs for the act of making a reproduction, think of how your institution might spend time doing other things that fulfill your mission and generate good will. If you can automate the delivery of high-quality reproductions, even better. Maybe you could do outreach and events to engage your community, or spend more time on friend and fund raising, or make more collections available. Controlling reproductions and charging punitive fees for exposing our collections are not good investments when you consider what might be gained by diverting those staff resources elsewhere.

\section{Alternatives for Revenue Generation}

Many special collections probably implemented a fee structure for reproductions to generate much-needed revenue. No doubt my recommendations will hurt the bottom line for several institutions, but there are other, more creative ways to generate revenue from your holdings by competing in the marketplace, rather than trying to control it. We might take a cue from museum stores and look to market some of our most interesting or visually arresting holdings. How about

\footnotetext{
22. Kathleen Connolly Butler, "Keeping the World Safe from Naked-Chicks-in-Art Refrigerator Magnets: The Plot to Control Art Images in the Public Domain through Copyrights in Photographic and Digital Reproductions," Hastings Communications and Entertainment Law Journal 21 (Fall 1998): 55-126.
} 
posters, note cards, t-shirts, mugs, or magnets? Here at UNLV, we forged a deal with a local company to sell repositionable wall stickers of Vintage Vegas, and we receive a percentage of their sales. ${ }^{23}$ Zazzle offers a similar deal. For example, see what you can buy from the Bancroft Library from their Zazzle store. ${ }^{24}$

In his 2003 SAA address, Hirtle described how Cornell University provided online, free access to an image of Abraham Lincoln, but the New York Times store offered the same image, with an easy-to-use order form, with options to matte and frame it, and charged a great deal more. The New York Times store offered a value-added service that customers were willing to pay for. ${ }^{25}$ There are many ways to promote our content; transforming a very small percentage of our holdings into desirable commodities, with the assistance of corporate partnerships, might be an option for those needing a substitute revenue stream. Rather than restricting access and use, capitalize on the public's desire to purchase vintage items as décor or other purposes. This commercial approach to marketing our holdings might allow us to satisfy demand in the marketplace without compromising our professional commitment to providing equitable access to our holdings.

\section{Conclusion}

As mentioned earlier, as I wrote this plenary presentation, I simultaneously rewrote the UNLV Special Collections' permission policies and fee structures, with assistance from our legal counsel. ${ }^{26} \mathrm{I}$ was inspired most by the policies and practices at the Beinecke Rare Book and Manuscript Library at Yale. ${ }^{27}$ Our new policies work better in our current environment where we are delivering more and more content online. We eliminated publishing fees, but we still charge scanning and service fees. ${ }^{28}$ We eliminated the requirement to ask us for permission when we do not own copyright. We are working toward making it possible for users to download high-quality images for public domain content and where we own copyright. Someday I hope to make high-quality downloads freely available for most of our content, with disclaimers about fair use and rights when copyrighted. ${ }^{29}$

23. Walls 360, "Vintage Vegas," available online at www.walls360.com/Vintage-Vegas-wall-graphicss/31598.htm [accessed 1 December 2014].

24. Zazzle, "The Bancroft Library," available online at www.zazzle.com/bancroft [accessed 1 December 2014].

25. Hirtle, "Archives or Assets."

26. Special Collections, University of Nevada, Las Vegas University Libraries, "Reproductions and Use," available online at https:/ / www.library.unlv.edu/speccol/research_and_services/reproductions [accessed 1 December 2014]. Provided as an appendix as well.

27. Beinecke Rare Book and Manuscript Library, "Permissions and Copyright," available online at http:/ / beinecke.library.yale.edu/research/permissions-copyright [accessed 1 December 2014].

28. Scanning and service fees aim to recuperate costs associated solely with the act of creating and furnishing a publishable quality reproduction. Scanning and service costs are partially subsidized, however, for students, faculty, and Nevada residents, in keeping with our mission.

29. The Beinecke Digital Collections is a model on this count. Find and download high-quality reproductions here: http://brbl-dl.library.yale.edu/vufind/. 
I have been asked about what makes for a good reproductions policy; and, after viewing more than 125 policies and forms, I found some worthwhile trends to emulate. ${ }^{30}$ The best policies do not have a requirement for a researcher to seek permission from the institution when the institution does not own copyright or when the material is in the public domain. These institutions do not charge use or permission fees, or at least do not charge these fees when the material is in the public domain or the material is copyrighted by another entity. These institutions explain or link to an explanation of "fair use." The policies also offer a clear statement about users' responsibility to research copyright for any material they wish to use and to gather any necessary permissions prior to using materials in excess of "fair use."

In conclusion, if your institution belongs to the 70 percent of those that require permissions to publish or the 55 percent that charge for publishing, I encourage you to go back and reexamine your permissions processes and fee structures. What values do you want your institution to represent? What role should your institution have in the marketplace for historical content? How should your institution help, or hinder, the progress of our culture?

30. See Merrilee Proffitt, "Do You Want to Be the 'Good Guys'? Reproduction, Permissions, and Copyright Assertions," Hanging Together (from OCLC Research, July 2014), available online at http:/ / hangingtogether.org/?p=3984 [accessed 1 December 2014]. 


\section{Appendix \\ University of Nevada, Las Vegas University Libraries Special Collections Revised Reproduction and Use Policies}

UNLV Special Collections provides copies of materials to facilitate private study, scholarship, or research. We welcome you to use materials in our collections that are in the public domain ${ }^{31}$ and to make fair use ${ }^{32}$ of copyrighted materials as defined by copyright law. ${ }^{33}$ Please cite ${ }^{34}$ us.

The copyright law of the United States (Title 17 United States Code) governs the making of reproductions of copyrighted material. Under certain conditions specified in the law, libraries and archives are authorized to furnish a reproduction. One of these specified conditions is that the reproduction is not to be "used for any purpose other than private study, scholarship, or research." If a researcher uses a reproduction for purposes in excess of "fair use," that researcher may be liable for copyright infringement.

\section{Request to reproduce items}

Requests to copy Special Collections material constitute an agreement that you will not reproduce, transfer, distribute, broadcast, publicly display, offer for sale, or otherwise use or publish any material subject to copyright, or a portion thereof, in excess of fair use, as defined by copyright law, without the express permission ${ }^{35}$ of the copyright holder.

Please note that while the UNLV Special Collections owns the materials in our collections, we usually do not own the copyright to these materials, except where it has been explicitly transferred to UNLV. You are solely responsible for determining the copyright status of materials and obtaining permission to use material from the copyright holder. Special Collections can not provide permission to publish or distribute materials when UNLV is not the copyright holder.

We reserve the right to limit the number of copies made; to restrict the use of rare and valuable items; and to deny a request because of copyright regulations, privacy rights, donor-imposed regulations, or other rights related issues.

\footnotetext{
31. Peter B. Hirtle, "Copyright Term and the Public Domain in the United States." available online at https: / / copyright.cornell.edu/resources/publicdomain.cfm [accessed 1 December 2014].

32. U.S. Copyright Office, "Fair Use," available online at http://www.copyright.gov/fls/fl102.html [accessed 1 December 2014].

33. U.S. Copyright Office, "Copyright Law of the United States," available at http://www.copyright. gov/title17/ [accessed 1 December 2014].

34. UNLV University Libraries Special Collections, "Citing Materials from the UNLV Special Collections," available at https://www.library.unlv.edu/speccol/research_and_services/citing [accessed 1 December 2014].

35. U.S. Copyright Office, "How to Obtain Permission," available at http:/ / www.copyright.gov/ circs/m10.pdf [accessed 1 December 2014].
} 


\section{Reproduction request form}

Please fill out and sign this reproduction request form ${ }^{36}$ completely and submit it to special.collections@unlv.edu or via fax to 702-895-2253

\section{Personal cameras and scanners}

With some exceptions, the use of cameras and scanners is permitted. There is no charge for use of cameras or scanners. Special Collections staff may forbid the use of cameras or scanners if you mishandle materials, or if your equipment poses any risk to our materials or causes disruption in our reading room.

\section{Fees and payment}

\begin{tabular}{|c|c|c|}
\hline \multirow[b]{2}{*}{ Photocopies } & Self-service & $\$ .15$ page \\
\hline & By staff & $\begin{array}{l}\$ .25 \text { page } \\
\$ 5.00 \text { surcharge for every } 100 \text { copies }\end{array}$ \\
\hline \multirow{4}{*}{$\begin{array}{l}\text { High resolution } \\
\text { digital scans }\end{array}$} & \multirow{2}{*}{$\begin{array}{l}\text { Students, } \\
\text { educators, } \\
\text { Nevada } \\
\text { residents }\end{array}$} & $\begin{array}{l}\text { Existing scan: } \\
\$ 2 \text { each up to } 20 \text { scans } \\
\$ 6 \text { each after } 20 \text { scans }\end{array}$ \\
\hline & & $\begin{array}{l}\text { New scan or adjustments to existing scan: } \\
\$ 5 \text { each up to } 20 \text { scans } \\
\$ 15 \text { each after } 20 \text { scans }\end{array}$ \\
\hline & \multirow{2}{*}{ Others } & $\begin{array}{l}\text { Existing scan: } \\
\$ 5 \text { each up to } 20 \text { scans } \\
\$ 15 \text { each after } 20 \text { scans }\end{array}$ \\
\hline & & $\begin{array}{l}\text { New scan or adjustments to existing scan: } \\
\$ 10 \text { each up to } 20 \text { scans } \\
\$ 30 \text { each after } 20 \text { scans }\end{array}$ \\
\hline $\begin{array}{l}\text { Audio or audio-visual } \\
\text { materials }\end{array}$ & \multicolumn{2}{|c|}{ Cost of labor, materials, and/or vendor charges } \\
\hline Research fees & \multicolumn{2}{|c|}{ No charge for first half hour; $\$ 40$ per hour thereafter } \\
\hline \multirow[t]{2}{*}{$\begin{array}{l}\text { Service } \& \text { invoicing } \\
\text { fees }\end{array}$} & $\begin{array}{l}\text { Students, } \\
\text { educators, } \\
\text { Nevada } \\
\text { residents }\end{array}$ & $\$ 3$ per order \\
\hline & Others & $\$ 10$ per order \\
\hline \multirow{2}{*}{ Rush fees } & 24 hours & $200 \%$ \\
\hline & 48 hours & $100 \%$ \\
\hline Shipping & \multicolumn{2}{|l|}{ At cost } \\
\hline
\end{tabular}

36. UNLV University Libraries Special Collections, "Reproduction Order Form," available at https://www. library.unlv.edu/sites/default/files/documents/pages/reproduction_request_form_1.pdf [accessed 1 December 2014]. 
Payment required in advance. Work begins after receipt of payment. Requesters may pay by cash, check or credit card. In some cases, for invoices totaling more than $\$ 200$, payment by electronic fund transfer (EFT) may be approved, but a fee of $\$ 10$ per transaction will apply.

\section{Use, copyright, and attribution}

Special Collections welcomes you to use materials in our collections that are in the public domain and to make fair use of copyrighted materials as defined by copyright law. Please cite us.

Materials held by UNLV Special Collections may be protected by United States Copyright Law and/or by the copyright laws of other countries. Copyright law protects unpublished as well as published materials.

Special Collections does not claim to control the rights for reproduction for all materials or images in its collections. Certain images or materials may be protected by copyright, trademark, privacy, publicity rights, or other interests not owned by UNLV. If UNLV does not clearly hold the copyright to an item, Special Collections cannot grant or deny permission to use that material.

In obtaining a reproduction from Special Collections, you assume all responsibility for determining whether any permissions relating to copyright, privacy, publicity, trademark, or any other rights are necessary for your intended use, and for obtaining all required permissions. Written permission from the copyright holders and/or other rights holders is required for publication, distribution, or other use of protected items beyond that allowed by fair use.

Special Collections will not do research concerning the existence and/or whereabouts of rights holders. To the extent that we provide available information, the Libraries do not warranty the accuracy of such information and shall not be responsible for any inaccurate information. Special Collections will not facilitate or execute requests for permission.

The Society of American Archivists provides further guidance about using copyrighted and unpublished materials. ${ }^{37}$ The U.S. Copyright Office provides information about How to Investigate the Copyright Status of a Work. ${ }^{38}$ When you cannot identify or locate the current copyright owner of a copyrighted work, the

37. Society of American Archivists, "Copyright and Unpublished Material," available online at http:// www2.archivists.org/publications/brochures/copyright-and-unpublished-material [accessed 1 December 2014].

38. U.S. Copyright Office, "How to Investigate the Copyright Status of a Work," available online at http:/ / www.copyright.gov/circs/circ22.pdf [accessed 1 December 2014]. 
copyrighted material is sometimes called an "orphan work." ${ }^{39}$ Columbia University Libraries $^{40}$ and the Society of American Archivists ${ }^{41}$ also provide advice about documenting searches for copyright owners and using orphan works.

When you use material, you must properly acknowledge UNLV Special Collections as the source of the material.

You also must not use the name of Special Collections, the University Libraries, or UNLV in any manner which creates any false association between you and the image, materials, the Libraries, and/ or UNLV, or that incorrectly implies any sponsorship or endorsement by the Libraries, UNLV, or any third party rights holder.

We appreciate receiving a copy of any published work that features our material.

If you have any more information about an item you've seen on our website or if you are the copyright owner and believe our website has not properly attributed your work to you or has used it without permission, we want to hear from you. Please contact special.collections@unlv.edu with your contact information and a link to the relevant content.

\section{Privacy and publicity rights}

You are solely responsible for addressing issues of privacy and publicity rights relating to your use of our materials. The rights of privacy and publicity are distinct from copyright. Although fair use is a defense to copyright infringement, it is not a defense to violating privacy or publicity rights.

An individual depicted in a reproduction has privacy rights as outlined in Title 45 CFR $46^{42}$ (Protection of Human Subjects). Special Collections reserves the right to require a release from individuals whose privacy may be violated by the reproduction of this image or materials.

The right of publicity is a person's right to control, and profit from, the use of his or her name, image, and likeness. This means that any use of a person's name,

39. U.S. Copyright Office, "Orphan Works," available online at http:/ / www.copyright.gov/orphan/ [accessed 1 December 2014].

40. Columbia University Libraries Copyright Advisory Office, "If You Cannot Find the Owner," available online at http:/ / copyright.columbia.edu/copyright/ permissions/if-you-cannot-find-the-owner/ [accessed 1 December 2014].

41. Society of American Archivists, "Orphan Words: Statement of Best Practices," available online at http:/ / www.archivists.org/standards/OWBP-V4.pdf [accessed 1 December 2014].

42. Office for Human Research Protections, "Code of Federal Regulations, Title 45 Public Welfare Department of Health and Human Services, Part 46 Protection of Human Subjects," available online at http:/ / www.hhs.gov/ohrp/humansubjects/guidance/45cfr46.html [accessed 1 December 2014]. 
image, or likeness for commercial gain is not permitted without his or her consent. Rights of publicity are governed by state laws, for example Nevada Revised Statutes $597.770-810 .{ }^{43}$

\section{Disclaimer}

In receiving a reproduction from our holdings, you assume all responsibility for infringement of copyright or other rights in your use of the material. You must agree to defend, indemnify, and hold harmless the Libraries, the University of Nevada, Las Vegas and its Regents, officers, agents and employees, from and against any and all liabilities, losses, demand, penalties, costs, expenses, attorneys' fees, lawsuits, fines, judgments, or causes of actions, including but not limited to claims relating to infringement of copyright, trademark, invasion of rights of privacy or publicity, or libel that arise either directly or indirectly from any use by the requestor of the images and/or materials provided by the Libraries, the University of Nevada, Las Vegas or its employees, Regents, or agents. 